\title{
Changes in Korean Corporate Governance: A Response to Crisis*
}

\author{
E. Han Kim and Woochan Kim**
}

\section{Introduction}

A decade has passed since the outbreak of the Korean financial crisis in November 1997. One of the fundamental causes of the crisis was widespread corporate value destruction, especially among the family-controlled business groups known as chaebol. Before the crisis, these business groups routinely pursued growth and market share at the expense of profitability and shareholder value. For some of the chaebol, size added to their political influence, which could be used to tilt the playing field in their favor. Being bigger also meant better access to external financing and lower borrowing costs, thanks in part to the "too big to fail" legacy. But another important factor driving this value-destroying growth was the so-called "private benefits" of controlling a larger corporate empire to the controlling shareholders, typically referred to in Korea as the "owners." In addition to the consumption of perks, the chaebols' "owners" commonly used "tunneling" and "asset-grabbing" schemes to transfer corporate value from their minority shareholders.

As we discuss in more detail below, one important factor motivating and enabling the chaebol to expropriate their minority shareholders has been the substantial gap between their "cash flow rights" - that is, their percentage claim on dividends and earnings - and their voting, or "control," rights. While

\footnotetext{
* This Article previously appeared in Vol. 20, No. 1 of Journal of Applied Corporate FinANCE 47-58 (Winter 2008), a Morgan Stanley publication.

** E. Han Kim is Fred M. Taylor Professor of Business Administration and Director of Mitsui Life Financial Research Center at the University of Michigan's Ross School of Business. Woochan Kim is Associate Professor of Finance at the KDI School of Public Policy and Management in Seoul, Korea.
} 
the cash flow rights of the controlling chaebol families have often been relatively small-about $20 \%$, on average-their control rights have been near absolute thanks to a web of complex cross holdings among affiliated firms. Such disproportionate control rights, together with various legal and sociopolitical impediments to shareholder activism, have also made the chaebol immune to the threat of hostile takeovers. Thus, as we argue in the pages that follow, the chaebol have largely avoided the disciplining forces of capital and corporate control markets, even as their distorted incentives have resulted in unprofitable growth, diversification, and massive destruction of value.

In a study (involving one of the present writers) that was commissioned by the Korea Stock Exchange prior to the 1997 financial crisis, the authors calculated the economic value added (EVA) produced by 570 non-financial Korea Stock Exchange companies in each year from 1992 through 1996. ${ }^{1)}$ After adding up the annual EVAs for each company over this five-year period, the authors concluded that only about $27 \%$ of the companies created or maintained shareholder value. In other words, nearly three-quarters of Korean companies did not generate sufficient operating profits to cover their capital costs over the five-year period preceding the crisis.

While this unchecked value destruction was reducing shareholder wealth and shrinking the value of its economy, Korea should have experienced substantial depreciation of its currency during the run-up to the crisis. However, the government maintained the value of the won at artificially high levels until it ran out of foreign reserves in November 1997. When lack of reserves forced the government to let the exchange rate float freely, the currency's value immediately plummeted. The won-dollar exchange rate more than doubled, rising from 964.4 to 1964.8, during the two months from the beginning of November through December 24.

The currency crisis coincided with a presidential election, and the ruling party was swept from office. The new administration proposed a number of reform measures, targeting primarily chaebol ownership and its governance structure. But, at this point, the crash in currency value was followed by a

1) EVA is calculated as net operating profits after taxes minus a charge for the cost of capital equal to WACC multiplied by total capital. See E. Han Kim, Myeong Kyun Kim \& Jaekyung Yi, Economic Value Added (EVA) of the Listed Companies, 98-01 The Korea Stock Exchange Report (February 1998) (in Korean). 
sharp increase in interest rates resulting from the tight monetary policy prescribed by the International Monetary Fund (IMF). The immediate result was that unemployment skyrocketed and GDP dropped sharply.

The crash of its currency was more than a financial blow to Korean citizens. The loss of Korean economic independence to foreign powers represented by the IMF was a public humiliation, an assault on the national psyche. Citizens lost faith in their leaders, questioning their authority and credibility. And in response to this national crisis of confidence, Korea suddenly exhibited the political will to make major governance reforms, an uncommon event in democracies. ${ }^{2)}$

The reform measures announced by the new administration were a mix of market-based solutions and government interventions. The governmentengineered, large-scale swaps of business units among the largest chaebolthe so-called "big deals" that were designed to force each chaebol to specialize in its core business - failed miserably, with serious unwanted side effects. This was not surprising since the new government played the role of corporate match-maker rather than allowing market forces to restructure the corporate portfolios. And as this experience demonstrated once again, politicians and government bureaucrats have neither the incentive nor the expertise to allocate resources to their highest-valued uses and users.

At the same time, however, new laws and regulations designed to increase corporate transparency, oversight, and accountability were put in place. And the effects of these laws and regulations on the quality of governance of Korean corporations have been unmistakably positive. Among this package of reforms, one major contributor to improved governance has been the lowering of barriers to foreign ownership of Korean companies. By the end of 2006, foreign ownership of listed Korean companies amounted to about 37\%, up from just 13\% in 1996. And in addition to the growing pressure for better governance from foreign investors, strong grass-roots reform movements have sprung up. Several newly formed non-governmental organizations (NGOs) have pressed for increased corporate transparency and

2) For a more detailed description of the causes of the financial crisis and the type of restructuring measures undertaken by the new administration, see E. Han Kim, Globalization of Capital Markets and the Asian Financial Crisis, 11 Journal of Applied Corporate FinAnCE 30-39 (Fall 1998). 
accountability, particularly in the largest chaebol. After witnessing the collapse of large chaebol once believed to be too big to fail, the Korean business community has shown a heightened awareness of the importance of increasing shareholder value as a strategy for national competitiveness and long-term corporate survival. And in recent years, such awareness has led to a number of voluntary as well as mandated reforms in Korean corporate governance.

In this article, we describe these reforms while assessing the current state of corporate governance in Korea. In so doing, we divide the subject of corporate governance into three broad categories-ownership structure, internal governance mechanisms, and external monitors - and discuss each in turn.

\section{The Chaebol and "Emperor-like" Management}

How well a company is governed is largely determined by various implicit and explicit contracts among the stakeholders of the firmmanagement, employees, investors, directors, and so forth-and the effectiveness with which the contracts are enforced. Such contracts differ among companies in terms of the degree of alignment between managerial and shareholder interests, the priority given to shareholder value by the board of directors, and the level of voluntary disclosure for external financing. The ability of corporate stakeholders to monitor and enforce such contracts depends on laws and regulations governing timely and accurate disclosure, managerial and board accountability, board independence, and protection of minority shareholders. It also depends on the extent of social and political acceptance of the concept of shareholder value maximization.

Before the crisis of 1997, neither the chaebol ownership structure nor Korean legal institutions encouraged effective corporate governance. In 1996, the controlling shareholders of the large chaebol owned an average of $23 \%$ of the outstanding shares, but effectively controlled $68 \%$ of the votes through various forms of cross and circular holdings in subsidiaries and related firms. ${ }^{3)}$

3) In classifying chaebol as "large," we used the designation of the Korea Fair Trade 
Such disproportionate control gave the chaebol owners the power to appoint the top managements and boards of their affiliated firms. Also important were the financing practices of chaebol affiliates, which have typically relied on the "internal capital markets" created by the conglomeration of numerous affiliated and related firms. Given this supply of internal funding, chaebolaffiliated firms have been able to avoid the disclosure necessary to obtain external financing, as well as the discipline-including the possibility of takeover - that comes with relying on outside equity capital.

Before the crisis, Korean laws and regulations were largely ineffective in protecting minority shareholders, ensuring timely and accurate disclosures, and preventing insider trading. Even the media, which are expected to expose corporate scandals and bad governance practices, were often captives of the chaebol, either through their direct ownership or their power to withhold advertising expenditures. For example, Samsung Group, Korea's largest chaebol, owned ChoongAng Daily, one of the two most widely subscribed newspapers. The Federation of Korean Industries, the lobbying organization for the chaebol and other large corporations, owns the Korea Economic Daily, one of the leading business newspapers in Korea. Other possible external sources of shareholder protection, such as institutional investors or activist block holders seeking value-increasing changes or encouraging takeover bids, were virtually non-existent.

In sum, before the crisis, the chaebol owners encountered few obstacles to practicing what Koreans call hwangje kyungyoung, or "emperor-like management."

\section{An Overview of the Changes}

Much has changed in Korean corporate governance during the ten years that have passed since the crisis. In a 2005 working paper, a group of four

Commission. The numbers are equally-weighted averages of individual firm-level cash flow rights and control rights. Group-level disparity, which is computed by size-weighted averages of firm-level numbers within the same group, is smaller because larger firms tend to have smaller disparities. The controlling shareholder's cash flow rights and control rights at the group level are $16 \%$ and $34 \%$, respectively. We include non-listed firms in our calculation. 
academics (including one of the present writers) developed a Korea Corporate Governance Index (KCGI) that is based on evaluation of five attributes of corporate governance: shareholder rights; board structure; board procedures; disclosure; and ownership parity. ${ }^{4)}$ Changes in the KCGI, together with the performance of the Korean stock market and a wealth of "anecdotal evidence," suggest a dramatic increase in the quality of Korean corporate governance during the post-crisis period. Between 1998 and 2004, the last year these data have been compiled, the KCGI for large listed Korean corporations (those with book asset values greater than about $\$ 2$ billion) jumped from 30.78 to 69.64 (out of a possible 100). ${ }^{5}$ )

One important contributor to the increase in Korea's governance index has been the emergence of large (non-chaebol) industrial corporations that have been recently privatized, including POSCO, now the world's third largest steel producer; KT, Korea's largest telecom provider; and KT\&G, Korea's largest tobacco company. The other major group showing notable improvements in the quality of governance is Korean banks that have received large infusions of foreign capital, including Hana, Kookmin, and Shinhan. In most of these groups of companies, a majority of the outstanding shares are held by foreign investors. $\left.{ }^{6}\right)$ All are run by professional-that is, non-family - managers under a great deal of public scrutiny. And since all these companies are listed on foreign stock exchanges that require financial statements prepared in conformity with either U.S. GAAP or IFRS, they provide far more disclosure than typical chaebol-affiliated firms. ${ }^{7)}$

4) The KCGI was compiled and presented by Bernard S. Black, Woochan Kim, Hasung Jang, and Kyung-Suh Park in their working paper, Does Corporate Governance Affect Firms' Market Value? Times Series Evidence from Korea (European Corporate Governance Institute Finance Working Paper No. 103, 2005). The numbers reported above represent updates of the indices presented in the original version.

5) For smaller listed firms with book value of assets less than 2 trillion won (about \$2 billion), the increase in KCGI was less dramatic, increasing from 22.96 in 1998 to 38.58 in 2003. These companies are subject to looser regulatory requirements concerning disclosure, intercorporate investment, cross holdings, and board composition.

6) As of December 10, 2007, foreign ownership of POSCO shares was $49 \%$, while foreign ownership of KT, which is subject to an upper ceiling of $50 \%$, was $46 \%$. The foreign ownership for the remaining four firms was well over $50 \%$.

7) POSCO, KT, Kookmin, and Shinhan are listed on the New York Stock Exchange, Hana on the London Stock Exchange, and KT\&G on the Luxemburg Stock Exchange. 
To illustrate the kind of changes that have taken place in the past decade, let's take a closer look at the governance system of POSCO, which is the second largest Korean corporation in terms of market capitalization (in the $\$ 50$ to $\$ 60$ billion range during the second half of 2007). We chose POSCO for a number of reasons. One, it was the first Korean company to list on the New York Stock Exchange, a step the firm took in 1994. Second, and perhaps even more telling, Warren Buffett had accumulated a $4 \%$ stake in the firm by the end of 2006, citing the firm's strong governance system. Third and last, one of the authors of this article has served as an independent director of POSCO since 2002, and is currently the firm's non-executive chairman.

Given POSCO's position as the first Korean firm to list on the NYSE, the list we provide below of the most important features of its governance system reflects NYSE listing requirements as well as the requirements of Sarbanes Oxley:

- The company is governed by a board of 15 people, including six executive "insiders" and nine independent outside directors.

- The CEO does not chair the board.

- The audit committee consists entirely of outside independent directors, two of whom are financial experts.

- The current public auditing firm was chosen through an open bidding process.

- The company complies fully with the internal control system required by the U.S. Sarbanes-Oxley Act.

- The bylaws allow cumulative voting, greatly increasing the ability of minority shareholders to elect their own representatives to the board.

- The company has no explicit anti-takeover devices in place and no golden parachutes for its executives. ${ }^{8)}$

Together, these features not only surpass global standard requirements, they also represent advances over most major American companies, where poison

8) POSCO does, however, have mutual shareholdings with a number of other companies (e.g., Nippon Steel Corporation and Hyundai Heavy Industries). Although these inter-firm share investments represent strategic alliances, they could be used to thwart hostile takeover attempts if the strategic partners decided to vote with POSCO management. 
pills are common and the majority of CEOs continue to serve as their board chairmen.

POSCO's system appears to be working for its non-investor stakeholders as well as its shareholders. Its stock price more than quadrupled during the past five years, and its leadership in corporate responsibility is widely recognized. As just one example, a recent issue of Business Week Japan (November 7, 2007) recognized POSCO as one of the 30 most socially responsible, "sustainable" companies in the world.

Of course, POSCO is not the only company in Korea with good governance. In addition to the banks and newly-privatized firms mentioned earlier, at least a dozen other companies (including SK Telecom, LG Telecom, and KTF) are widely regarded as effectively managed, well-governed companies - indeed, on a par with the best-governed U.S. companies. But, as suggested, these companies present a striking contrast to the majority of Korean firms affiliated with the chaebol, where the quality of governance systems is highly variable and the propensity to reform unclear.

\section{Back to the Chaebol Problem: Ownership Structure}

The core of the chaebol's governance problem lies in its ownership structure. It is typically a web of complex cross-shareholdings, often involving a number of circular shareholdings with no clear holding company. In December 2004, the Korea Fair Trade Commission (KFTC) began to disclose the intra-group ownership structures of the chaebol on its website, ${ }^{9)}$ making it easier to trace the actual share ownership and control rights belonging to the chaebols' owners.

Our analysis of this data shows that during the period 1997-2005, the average percentage of shares owned by the controlling shareholder (family) was only $22 \%$, while effectively exercising control over $69 \%$ of the voting rights through cross and circular holdings. ${ }^{10)}$ In other words, the average gap between cash flow rights and control rights for chaebol-affiliated firms was

9) http:/ / groupopni.ftc.go.kr

10) These numbers are based at the individual firm level. 


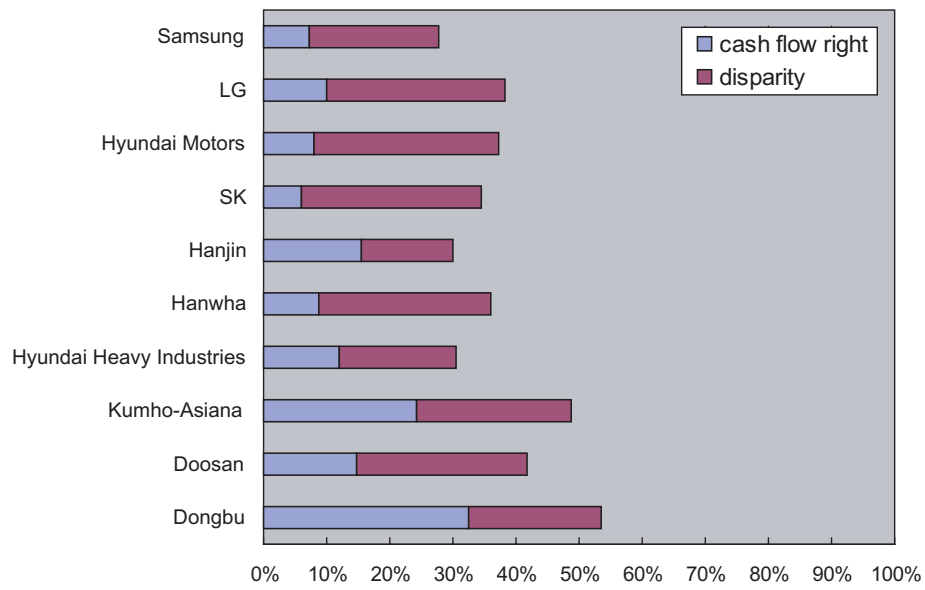

Figure 1-A. Size-Weighted

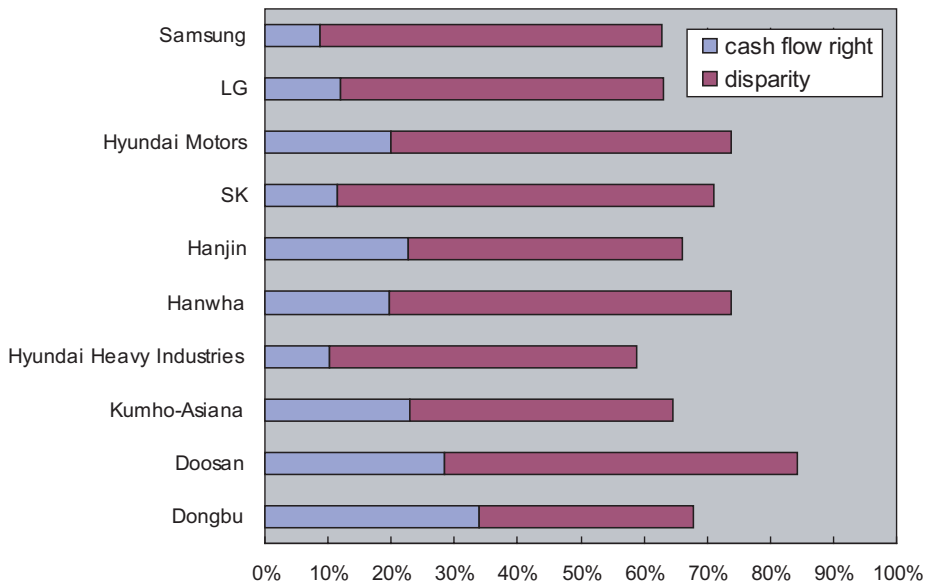

Figure 1-B. Equally-Weighted

Figure 1. Control-Ownership Disparity of the Top 10 Chaebol (as of April 2004)

Size is determined by the book value of total assets. Control rights are the sum of cash flow rights and disparity. Figure 1-A shows size-weighted averages of firm-level measures within each group, and Figure 1-B shows equal-weighted averages of firmlevel measures within each group. Because smaller firms tend to have larger disparities, group-level disparities are higher using equal weightings. 
close to $50 \%$ ! (Figure 1 shows the difference between the cash flow and control rights for the ten largest chaebol in Korea as of April 2004.)

A large disparity between cash flow rights and control rights is a warning signal, an indication of the strength of the controlling shareholders' incentives to transfer wealth from their minority shareholders. When a controlling shareholder owns $22 \%$ of the outstanding shares, for example, diverting \$100 worth of corporate assets for private uses provides the shareholder with a net gain of $\$ 78$. And a large disparity makes it easier to divert assets. In 2006 the People's Solidarity for Participatory Democracy (PSPD), the leading shareholder activist group in Korea, documented 70 cases of "tunneling" that is, the transfer of public corporate assets at below-market prices to other, often private, family-owned entities - by chaebol owners during the period 1995-2005. ${ }^{11)}$ Of the 70 cases, 30 were classified as appropriating valuable corporate opportunities; 20 as illegal securities transactions, such as selling securities to family members at a discounted price; and the remaining 20 as illegal related-party transactions. ${ }^{12)}$ What's more, a 2007 report by another NGO, Solidarity for Economic Reform (SER), identified information technology subsidiaries established within chaebol as a favorite tunneling tool, shifting wealth from public companies to privately owned family firms. $^{13)}$

An alternative to the typical chaebol ownership structure is a holding company format, a corporate organizational structure not permitted in Korea until 1999. That year, in an effort to ease the restructuring process for distressed chaebol after the financial crisis, the government started to allow holding company structures through a revision of the Monopoly Regulation and Fair Trade Act. In 2003, LG Group, the second largest chaebol at the time, was the first to convert into a holding company. LG was soon followed by

11) People's Solidarity for Participatory Democracy, Report on the Tunneling Activities of 38 Chaebol FAmilies (2006) (in Korean).

12) An example is LG Chemical's sale in 1999 of its LG Petrochemical shares to LG group family members at a heavily discounted price. In 2002, LG Petrochem was listed and the family members earned combined profits of approximately $\$ 200$ million dollars on the transaction. This case of self-dealing later resulting in a derivative suit that was won by the plaintiffs in 2006, with no appeal by LG family members.

13) Solidarity for Economic Reform, Why Are Chaebol Families Fond of IT Firms? 5 Economic Reform Report (2007) (in Korean). 


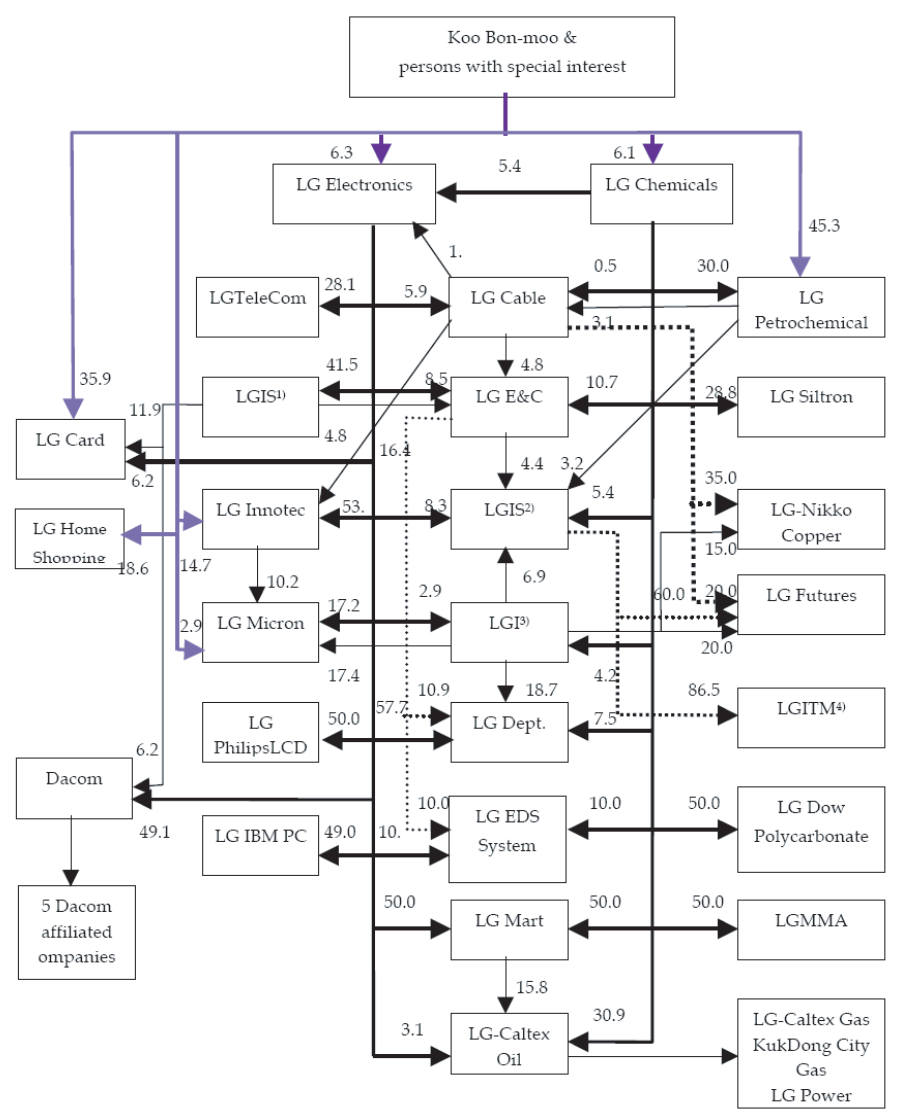

1. LGIS: LG Industrial Systems

2. LGIS: LG Investment \& Securities

3. LGI: LG International Corp.

4. LGITM: LG Investment Trust Management

Figure 2-A. Before Transformation (December 2000)

other large chaebol, including SK, the energy, chemical, and telecom conglomerate, and CJ Corporation, with major investments in food processing, retail, and entertainment. Figure 2 provides a diagram of the LG Group ownership structure before and after its conversion to a holding company structure, illustrating that the holding company structure makes the ownership structure less complicated and less opaque. A holding company also effectively eliminates the "chairman's office" - the center of group 


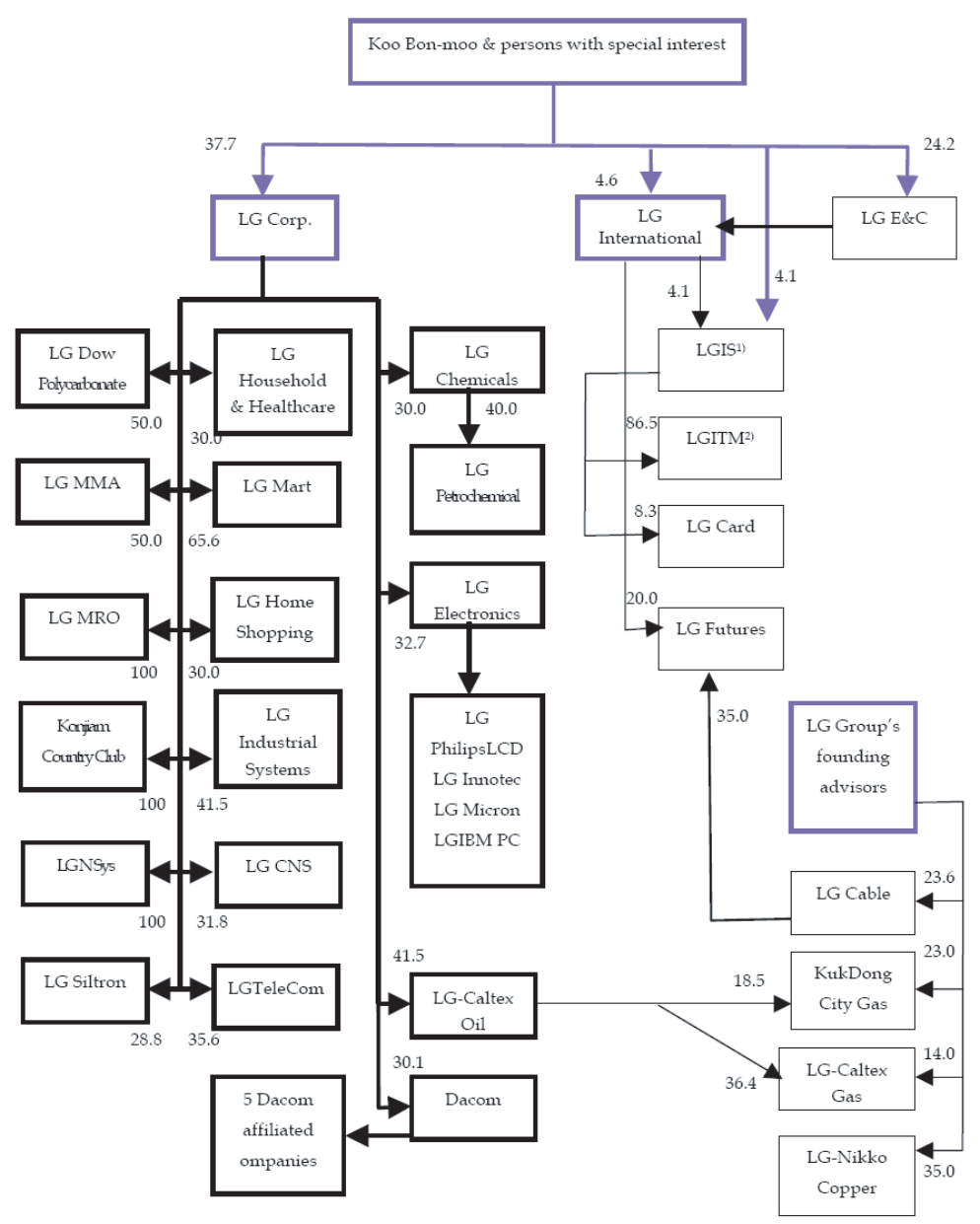

1. LGIS: LG Industrial Systems

2. LGITM: LG Investment Trust Management

Source: Joo-Young Lee, Simpler Ownership Structure for LG Group, Center for Good Corporate Governance Issue Report (February 12, 2003).

Figure 2-B. After Transformation (February 2003)

Figure 2. Ownership Structure of LG Group before and after its Conversion to a Holding Company Structure.

LG Corp. is the holding company and its member firms are highlighted using bold lines in black. Note that some member firms continue to be outside the holding company structure. 
control, with no legal status and hence no accountability. ${ }^{14)}$

\section{The Current State of Korean Corporate Governance}

We now discuss in more detail how Korean corporate governance has evolved in terms of internal governance, and then describe the growing presence of external governance monitors and active investors with the ability to bring about corporate change.

\section{Internal Mechanisms}

There are two major internal corporate mechanisms for achieving effective corporate governance: (1) the alignment of executive compensation and managerial incentives with shareholder value; and (2) oversight and control by the board of directors. And let's begin with managerial pay and incentives.

\section{1) Better Incentives}

The most common way to align managerial incentives with shareholder value maximization is performance-based pay, which can be linked either to stock prices and/or measures of operating profitability. Before the 1997 crisis, merit-based compensation was largely shunned by Korean companies, whether affiliated with chaebol or not, and executives and employees at all levels were paid almost entirely on the basis of rank and seniority. When profits were higher, employees received higher bonuses, but the amount of the individual bonuses depended largely on rank and seniority rather than performance. The only way an employee could be rewarded for superior performance was to get promoted faster than others, but early promotions were uncommon.

14) Because affiliated firms cannot hold the shares of a parent company in a holding company structure, there is no disparity between cash flow rights and control rights in the parent company. For the affiliated firms, however, the disparity did not decrease noticeably because the parent's ownership of affiliated firms can be as low as $20 \%$. Since the controlling family directly holds shares only in the parent company and two layers of pyramidal structure are allowed, the companies at the bottom of the control chain can have large disparities between cash flow and control rights. 
Although such pay practices clearly reflected the country's Confucian cultural heritage, with its emphasis on hierarchy and group harmony, they were also consistent with the chaebol owners' private incentives. If company executives were instead intent on maximizing shareholder value in order to increase their own rewards, they would less inclined to initiate, or cooperate with, tunneling schemes designed to shift profits and valuable assets out of their companies.

As the financial crisis led to numerous bankruptcies, including that of the Daewoo Group, the second largest chaebol at the time of default in 1999, the Korean business community became increasingly aware of the need to increase shareholder value for long-term survival and competitiveness. And, as a direct consequence, the Korean seniority-based, egalitarian compensation system came under heavy criticism. Companies gradually began to adopt some form of performance-based pay linked to reported earnings or other accounting-based measures of profit, EVA, and/or their stock prices. Stock options were introduced in 1997 ${ }^{15)}$ - and by October 2005, 139 listed companies (over $20 \%$ of the 657 firms then listed on the Korean Stock Exchange) had granted stock options to their executives. ${ }^{16)}$ Also worth noting, Korean companies have been required to expense executive stock options using the Black and Scholes formula since January, 2004. And there have been no Korean option "back dating" scandals like those in the U.S., perhaps reflecting Korean firms' greater consciousness of the costs associated with granting options,

One study of 246 Korean listed companies over the period of 1998-2001 (involving one of the present authors) reported that, for the entire sample (both chaebol-affiliated and otherwise), managerial compensation was significantly related to stock market performance, and that the sensitivity of pay to stock performance was comparable to that in the U.S. and Japan. ${ }^{17)}$ More interestingly, this linkage between Korean pay and performance was

15) Turbotek, a non-listed venture firm, was the first to introduce stock options to attract and motivate skilled workers.

16) Press Release, Stock Option Grants among Listed Firms (October 2005) (on file with Korea Listed Companies Association) (in Korean).

17) Takao Kato, Woochan Kim \& Ju Ho Lee, Executive Compensation, Firm Performance, and Chaebol in Korea: Evidence from New Panel Data, 15 Pacific-BAsin FinAnCE Journal 36-55 (2007). 
driven entirely by the non-chaebol companies, with no significant relation observed for chaebol-affiliated firms. The appointment of top executives in chaebol-affiliated firms has generally been the prerogative of the chaebol owners, who are not likely to encourage firm value maximization when they intend to pursue tunneling and other forms of private benefits of control.

\section{2) Better monitors}

Another important change to Korean internal corporate governance has been the introduction of independent outside directors. Immediately after the crisis, regulations were put into effect requiring that at least one-quarter of the board members of all listed companies be independent outside directors. In 2001, the required percentage of independent directors was increased to $50 \%$ for companies with a book value of assets exceeding 2 trillion won (about \$2 billion). At least two studies have shown that the larger companies that were required to increase their percentage of independent directors also experienced significant share price increases when the reforms were announced in the second half of 1999. ${ }^{18)}$ The same studies also reported that those companies afterward reported greater increases in profits, fewer asset sales to related parties (i.e., tunneling), and more frequent board meetings with higher attendance rates than a control group of smaller companies not required to increase the percentage of independent directors. In sum, the requirement for more independent outside directors on the board seems to have had positive effects on the quality of governance, providing better protection for minority shareholders.

Skeptics, of course, question the actual degree of independence of outside directors, pointing out that many nominally independent directors in fact have past ties to the firm or chaebol owners - former executives, current and former executives of a related firm or creditor bank, and lawyers with past or present business ties. A recent report by the SER concludes that almost $20 \%$ of the independent directors of 211 chaebol-affiliated publicly listed firms had

18) See Bernard S. Black \& Woochan Kim, The Effect of Board Structure on Firm Value: A Multiple Identification Strategies Approach Using Korean Data (European Corporate Governance Institute Finance Working Paper No. 179, 2007); see also Jongmoo Choi, Sae Won Park \& Sean Sehyun Yoo, The Value of Outside Directors: Evidence from Corporate Governance Reform from Korea, Journal of Financial and Quantitative ANALYsis (forthcoming). 
past or present ties to the firm on whose board they serve. ${ }^{19)}$ To look at the brighter side, however, this finding also means that over $80 \%$ of the board members are fairly independent. Skeptics also criticize corporate boards for rubber-stamping management proposals, pointing to relatively low rejection rates of management proposals by the boards. The business community responds to this charge by attributing the low rejection rates to management's careful preparation and prior consultation with their boards.

We believe there is an element of truth in both sides of this argument. For an illustration of how independent directors can and have made a difference in a Korean company, see the story of SK Telecom.

\section{SK Telecom and its Outside Directors}

Actions taken by outside directors of SK Telecom in 2003 illustrate the benefits of truly independent directors. In February 2003, prosecutors uncovered an accounting fraud of 1.5 trillion won (roughly $\$ 1.5$ billion) at SK Global, a distribution and logistics company and a member firm of SK Group (the third largest chaebol at that time). On May 19, creditor banks disclosed their due diligence report revealing that SK Global's book value of equity had negative 4.4 trillion won. Soon thereafter, SK Group pledged group-wide financial support for SK Global, which included a debt-to-equity swap and a promise to improve SK Global's yearly EBITDA from 279 billion to 436 billion won.

The support plan had to be approved by the board of each member firm. The actions taken by the boards of the two flagship companies of the group, SK Corporation (an energy and chemical company) and SK Telecom (a wireless telecom company), contrasted sharply. The board of SK Corporation approved the plan; the board of SK Telecom rejected it. The two boards were differentiated by the true independence of SK Telecom's outside directors from management and the controlling Chey family. In particular, two outside directors of SK Telecom were elected in March 1998 at the recommendation of minority shareholders. The two directors believed that the group support plan to rescue SK Global was harmful to SK Telecom's shareholders and

19) Solidarity for Economic Reform, The Independence of Outside Directors, 06 EcONOMIC REFORM REPORT (2007) (in Korean). 
persuaded the majority of outside directors to vote against the plan. (SK Telecom's articles of incorporation require approval by a majority of outside directors of related-party transactions exceeding 10 billion won.)

Although SK Telecom's refusal to join the group-wide support plan did not prevent the creditor banks from restructuring their debts and bailing out SK Global, SK Telecom was freed from the group-wide risk originating from SK Global. During the three-day window surrounding SK Telecom board's decision to reject the group support plan, its share price jumped by $8 \%$-and foreign ownership of the stock increased from $39.23 \%$ to $41.45 \%$.

\section{External Governance Mechanisms}

The independence of outside directors and their willingness to take assertive action against management have also been questioned in the U.S. But, at least until recently, there has been one important difference between the U.S. and Korea in this regard. When U.S. boards fail to take proper actions against poorly performing management, activist institutional investors or block holders often call for disciplinary actions by the board that are aimed at increasing shareholder value. Sometimes these actions succeed, often with help from the media. But when such external pressures fail in the U.S., the market for corporate control provides a solution by making the underperforming firms the targets of hostile takeover bids. Before the 1997 crisis, these external forces were not in place in Korea. Since the crisis, however, the legal and institutional environments in Korea have changed substantially, and a number of players have emerged as key external monitors and "enforcers."

For external monitors to function properly, they need access to information and enforceable rules that ensure transparency and accountability. Korea has undertaken several important reforms with this end in mind. In 2004 it enacted its own version of Sarbanes-Oxley. The Korean version of SOX and related regulations require, among other things, certification of periodic financial reports by the $\mathrm{CEO}$ and the $\mathrm{CFO}$, and a change in auditors after six continuous years of engagement. In 2007 the Financial Supervisory Commission (FSC) also announced a plan for the gradual adoption of the International Financial Reporting Standards (IFRS), with all listed firms having to conform to IFRS by 2011. 
To give bite to these new regulations, Korea recently introduced a law permitting securities class action suits. The law applies to all publicly traded companies that are found guilty of false disclosure in their company prospectus or quarterly, semi-annual, or annual reports - and to companies convicted of insider trading, market manipulation, or negligent external audits.

Derivative suits are another potentially important deterrent and legal tool for external monitors that have been used in Korea with considerable effectiveness. According to a 2007 SER study, 17 of the 40 suits filed and adjudicated during the past 10 years (1997-2006) were decided for the plaintiffs. ${ }^{20)}$ Among the best-known of these cases were suits filed against the managements of Korea First Bank in 1997, Samsung Electronics in 1998, and LG Chemical in 2003. In particular, the suit against Samsung Electronics was a wake-up call for all directors serving on the boards of chaebol-affiliated firms. Because Samsung Electronics' directors were not covered by D\&O insurance, the directors and Chairman Kun-Hee Lee, the controlling shareholder of Samsung Group, had to pay almost 20 billion won (about $\$ 20$ million) to the company out of their own pockets. Korean subscriptions to D\&O insurance surged soon after the district court verdict in December 2001.

In Korea, potentially effective external monitors and enforcers include shareholder activist NGOs (non-profit, non-government organizations), institutional investors, foreign block holders, and the media.

NGOs, which are typically funded by membership fees, have played an unusually important role in promoting corporate governance reform in postcrisis Korea. The best-known are PSPD and SER. These two NGOs have filed most of the derivative suits against chaebol-affiliated firms for malfeasance, and played a major role in prodding the Korean government to enact various reform measures and prosecute controlling shareholders for white-collar crimes.

In 2006, one of the founders of PSPD helped to create an activist governance fund, the Korea Corporate Governance Fund (KCGF), which is managed by Lazard Asset Management LLC based in New York. ${ }^{21)}$ The fund

20) Solidarity for Economic Reform, Shareholder Derivative Suit since 1997, 09 ECONOMIC REFORM REPORT (2007) (in Korean).

21) In the interest of full disclosure, the second author of this article is a member of SER'S 
is more commonly known as the Jang Hasung Fund, named after the shareholder activist who now advises it. The fund targets small-to-medium sized companies listed on the Korea Stock Exchange, engages in a dialogue with management with the aim of improving governance practices and increasing shareholder value, and takes hostile action if management response is deemed inadequate.

To the extent we can judge from the market's initial response, the fund's activities appear to be good news for shareholders. A 2007 study shows that the stock prices of companies targeted by KCGF increased significantly on the announcement of the targeting. ${ }^{22)}$ Moreover, even firms not targeted by KCGF experienced positive stock price reactions at the announcement of KCGF's acquisition of target company shares, with greater price jumps for non-target firms with lower quality of governance as measured by a governance index produced by Korea Corporate Governance Service (KCGS). To cite one dramatic example, in August 2006 when KCGF announced that it was buying $5 \%$ of its first target, Dae-Han, the company's stock price, as shown in Figure 3 , jumped by over $200 \%$ in about a month's time.

Another institutional investor with large potential to improve Korean corporate governance is the National Pension Fund (NPF). In December 2005, the NPF management committee included in its statement of proxy voting principles and guidelines a clear declaration that proxy voting should be carried out for the sole purpose of enhancing long-term shareholder value. The NPF has also committed to disclosing its votes no more than 14 business days after a shareholders' meeting, allowing outsiders to monitor whether the NPF is actually living up to its principles and guidelines. Part of the promise comes from the realization that the amount of assets under management by the NPF-about $\$ 240$ billion based on the exchange rate as of September 2007 -represents almost $20 \%$ of the Korean stock market's total capitalization of $\$ 1.2$ trillion. With its current investment in domestic equity of $\$ 37$ billion, the NPF's impact on Korean corporate governance could exceed the combined effect of CalPERS and other U.S. public pension funds in strengthening the

Policy Advisory Committee and of a group that serves as a consultant to KCGF.

22) See Jung Yong Choi, Dong Wook Lee \& Kyung-Suh Park, Corporate Governance and Firm Value: Endogeneity-free Evidence from Korea (mimeo, 2007). 


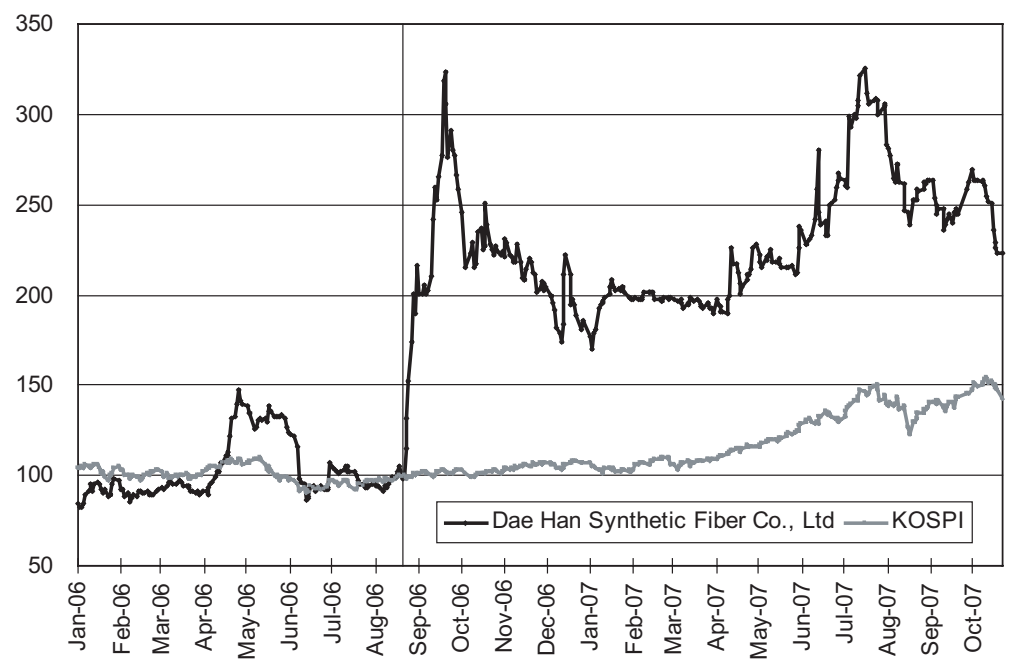

Figure 3. Share Price Impact of the Activist Korea Corporate Governance Fund This figure shows the share price movements of Dae Han Synthetic Fiber Co., Ltd. around the announcement that it became the first target of the activist Korea Corporate Governance Fund (KCGF). KCGF disclosed its 5\% ownership on August 23, 2006. The share price of Dae Han and the Korea Stock Price Composite Index (KOSPI) are normalized to 100 as of August 22, 2006.

accountability of U.S. management and boards.

Although there have been many M\&A transactions in Korea since the 1997 crisis, hostile takeover bids against underperforming management have been relatively rare. The external pressure on companies exerted by the Korean market for corporate control stems mainly from activist foreign block holders. Two of the most notable cases have been a proxy fight by Sovereign Asset Management against the management of SK Corporation and the attempt by Icahn Partners, jointly with Steel Partners, to break up KT\&G. Although Sovereign lost the proxy fight, its actions contributed to an increase in the share price of SK Corporation of more than $500 \%$ over a 16 -month period. To win the proxy fight, the management of SK Corporation had to promise major improvements in transparency and governance-promises it kept by revamping its board structure, improving governance practices, and converting to a holding company structure. In the case of KT\&G, although the attempt to break up the firm was unsuccessful, the dissidents won a proxy fight against management and secured a board seat. 
Additionally, a 2007 study involving one of the current authors provides strong evidence of the important role of foreign block holders in improving Korean corporate governance. ${ }^{23)}$ Since March 2005 all block holders in Korean companies with more than $5 \%$ ownership have been required to state whether they intend to be "passive" or "active" investors, and to declare any changes in their intent over time. The study shows that when foreign block holders announce they are switching their position from passive to active, the stock prices of those companies increase significantly, anticipating the holders' attempts to take more active roles in firm management and governance. And when the anticipated level of future activism is high, as indicated by the number of areas in which the block holder intends to engage actively, stock prices increase by $6 \%$ on average.

Finally, the Korean media have become more active monitors of large corporations. The traditional media now openly report corporate scandals and malfeasance committed by the largest and most powerful chaebol. The catalyst for this change has been the Internet. With high-speed broadband connection reaching almost $90 \%$ of Korean households at the end of 2006, Korea is one of the most Internet-connected countries in the world. Numerous Internet-based news organizations and websites have sprung up since the crisis and, with few ties to big business, they are not afraid to expose corporate wrongdoing. Because most young people rely heavily on such Internet-based news, the traditional media have little choice but to report corporate problems.

Although Korean corporations now face increased external pressure to practice good governance, some of the pressures are still emerging. For example, securities class action suits against companies with book values of assets below 2 trillion won (again, about $\$ 2$ billion) were not permitted until January, 2007. Furthermore, the legal hurdles to file class action and derivative suits are much higher than those in the U.S. In addition, a backlash against the Korean reform movement led opponents of full disclosure to argue successfully in 2006 that 129 of the 200 disclosure items are unnecessary for minority shareholder protection, scaling back mandatory disclosure. In response, the SER has maintained that 86 of these 129 deleted items could

23) See Woochan Kim, Woojin Kim \& Kap-Sok Kwon, Value of Shareholder Activism: Evidence from the Switchers (mimeo, 2007). 
provide valuable protection for minority shareholders.

Another cloud over the future of Korean corporate governance is being cast by the intensity of the current debate over anti-takeover measures. Korea up to this point has not permitted poison pills, dual class shares, or golden shares-all powerful anti-takeover devices limiting the ability of the market for corporate control to discipline poorly governed companies. However, big business lobbying groups argue that such protective devices are necessary for management to focus their full attention and energy on long-term business planning. Yet another anti-takeover measure under consideration is passage of an act similar to the U.S. Exxon-Florio Act that protects American companies from a foreign takeover for national security concerns.

So far there is no clear consensus on any of these anti-takeover measures in Korea. Even government agencies disagree. For example, the Ministry of Finance and Economy has taken a firmly pro-market position, stating that any anti-takeover measures are harmful to the economy. On the other hand, the Ministry of Commerce, Energy, and Industry has taken a more sympathetic view of business lobbying efforts to introduce these anti-takeover devices.

\section{Concluding Remarks}

In this article we describe the evolution of Korean corporate governance since the 1997 financial crisis. Any such discussion inevitably involves the chaebol because of their dominant role in the economy. The chaebol are widely credited with helping lead the backward Korean economy of the 1960s into its current position as the eleventh largest economy in the world. At the same time, however, they are blamed-and rightly so-for much of the corporate value destruction leading to the financial crisis. Accordingly, many governance reform measures triggered by the crisis have targeted chaebol.

Although some reform measures have been unsuccessful or had undesirable side effects, their overall impact has been positive. Most notable are improved corporate transparency, better alignment of managerial incentives with shareholder value, greater managerial accountability, and more effective oversight by the board. External monitors and enforcers of good governance, largely non-existent before the crisis, have emerged to play important roles in improving Korean corporate governance. 
The best governance practices in Korea today can be seen mainly in three kinds of corporations: (1) newly privatized companies; (2) large corporations run by professional management; and (3) banks with substantial equity ownership in the hands of foreign investors. The governance practices of many of these companies meet the global standard. At the other end of the spectrum, however, are many large chaebol-affiliated or family-run firms that refuse to change and circumvent regulatory reform measures. Also worth noting is that such resistance to change has not been without consequences for the controlling shareholders, several of whom have gone to jail for whitecollar crimes, often linked to bad governance.

Having said this, there are also marked differences in governance practices among the chaebol. Some have transformed their web of cross- and circular shareholdings into holding company structures, making their ownership clearer and less complicated. Some of the flagship companies affiliated with these chaebol now have governance practices that are on a par with those of well-governed U.S. companies. But many others continue to resist change and actively lobby against reforms.

It appears that some of these lobbying efforts are working. Not only does the political will for governance reform appear to be losing momentum, there also are signs of a growing backlash against reforms recently implemented. Although the recent reduction in the number of mandatory disclosure items is troubling, more disturbing is the current push to allow American style antitakeover devices, which, if successful, would clearly weaken the disciplinary effect of the market for corporate control.

What will Korean corporate governance look like in the future? As in the U.S. and throughout the world, some companies will practice good governance while others will not. ${ }^{24)}$ At this point, however, it is difficult to predict whether the average quality of Korean governance will continue to

24) There are wide within-country variations in the quality of corporate governance among companies in emerging markets. For a discussion of firm-level determinants of the quality of governance and the effect of governance on firm valuation, see Art Durnev \& E. Han Kim, To Steal or Not to Steal: Firm Attributes, Legal Environment, and Valuation, 60 Journal of FinANCE 14611493 (June, 2005), and Art Durnev \& E. Han Kim Explaining Differences in the Quality of Governance Among Companies: Evidence from Emerging Markets, 19 Journal of AppliEd CoRPORATE FinANCE 16-24 (Winter 2007). 
improve. With the reform movement losing its momentum, vested interest groups may succeed in eroding some of the gains already made. Much of the outcome will eventually depend on swings in socio-political moods, as well as on the globalization of trade. Because the Korean economy is so closely linked to foreign trade and capital, continued globalization will provide pressure for further improvement in corporate governance through both product and capital markets. Unfortunately, globalization appears to be on the defensive everywhere, even in the U.S, the self-proclaimed champion of free trade. This negative political climate surrounding globalization is the major threat to the future of Korean corporate governance. 